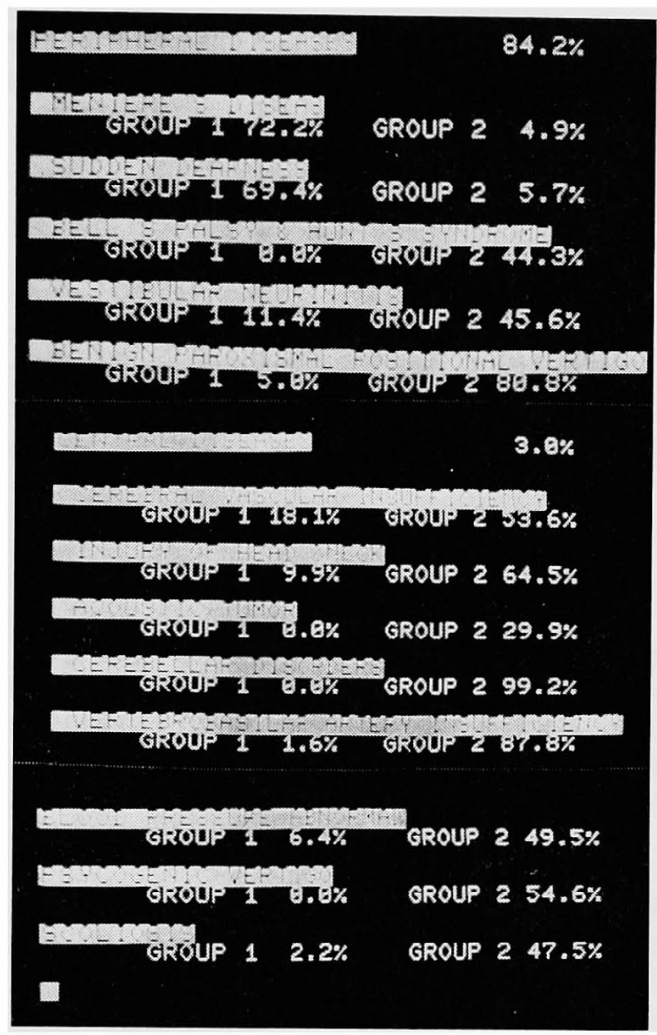

図 1

\title{
147. めむい平衡障害患者の年齢構成
}

\section{一 北里大病院 7 年間の集計 -}

徳增厚二・川野六郎・田代直樹・鈴木 徹・五島一吉・広瀬陽子・設楽哲也（北里大）

北里大学病院開設の 1971 年 8 月より 1978 年 7 月まで 7 年間飞めまい外来と平衡機能検査室で扱われた患者数は 6,523 名であった. その年度別推移は病院外来新患総数 の增加と平行して始めの 3 年間には增加しその後は年間 約 1,000 人とほほ一定であった.

北里大病院はその所在地である相模原市からの患者が 最も多い. 1975年度国勢調査での相模原市人口は 377,214 名でその中60歳以上は6.0\% 過ぎず若年，壮年層が多 い. めまい外来総数 6, 523 名では 60歳以上は $16.8 \%$ て 市人口年龄構成に比し高齢者が多い。1975年のめまい外 来患者数 999 名についても $17.7 \%$ で同様であった．同 年の北里大学病院新患数 85,834 名の居住区別では相模 原市が $36.5 \%$ であり，相模原市人口の 1,000 人に 1 人 がめまい外来を訪れたことになる。

めまい外来の患者の疾患分類では末梢前庭性障害“ $\mathrm{P}$ ” が $22.7 \%$, 中枢障害 “ $C$ ” 茫 $28.1 \%$, 全身的原因のも

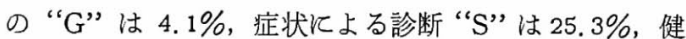
康診断 “ $\mathrm{H} ”$ は $5.0 \%$, 診断未定 “U” は $14.7 \%$ であ った. 60 歳未満 5, 428 名と 60 歳以上 1,095 名飞ついて それぞれ分類すると60歳未満では末梢性疾患が多く, 60 歳以上では中枢障害が多かった。（図 1)

各疾患別の年齢構成でみると末梢前庭性障害 1,478 名 で60歳以上は $11.1 \%$ 飞対して中枢性障害 1,835 名では 60歳以上が $25.2 \%$ であった.

末梢前庭障害では中耳炎, 内耳炎, 感音性難聴, メ二 エール病, 突発性難恥, 良性発作性頭位胘最症が主なも のであり, 年龋別では60歳以上において中耳炎, 内耳炎 は減少し, 感音性難聴, 良性発作性頭位胘最症が增加し た.メニエール病では60歳未満と60歳以上とで特に末梢 疾患の中の比率では差がなかった. 中枢障害の主なもの は脳血管障害, 頭部外第, 脳腫湯, 変性疾患, 高血圧症 が主なものであり，60歳未満では頭部外傷，脳腫察が多 


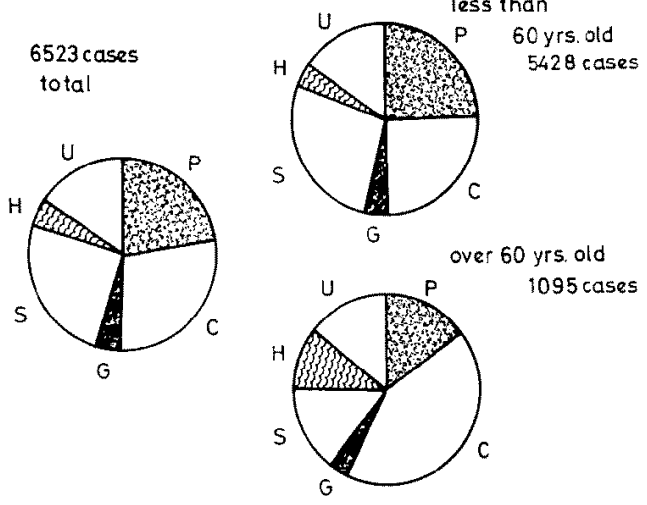

図 1

く60歳以上では脳血管障害，高血圧が多かった。60歳以 上で脳血管障害が $64.3 \%$ をしめ特に多かった。

全身的原团としては頸性，心因性，自律神経失調，起

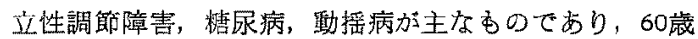

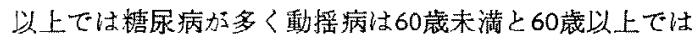
特に差はなかった。

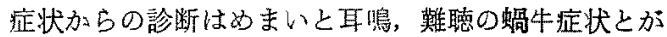
どのよろに起る加によるるので他の末梢性, 中枢性，全身 性原因の疾患夲除外してある，反復性聴平衡觉障害 13.2 $\%$, 反復性平衡賞障害 $44.0 \%$, 笔発性德平衡觉障害 $1.8 \%$, 単登性平衡賞障害 $11.1 \%$ ，誘発性平衡賞障害 $24.0 \%$, 持続 性平衡覚障害 $5.7 \%$ であった。これらの比率は60歳末満 と60歳以上で特沉差はなく，反復性平衡觉障害と誘発性 平衡觉媁害とが多数をしめた。

末梢萠定障害のみ二エール病，レルモワイエ症侯群， 突発性難聴, 発作性頭位脑最症, 前庭种経炎, 八ント症候 群はいづれも30歳代，40歳代，50歳代に多くみられこれ はメ二エール病の厚生省研究の報告と一致した。

中枢性疾患儿多くをしめる脳血管障害, 椎骨脳底動脈

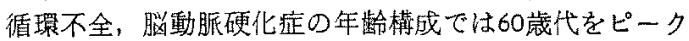
として增加を示した（図 2)。性别で特徴的なことは相模 原市総人口で男性は51\%であったのに対して䋞血管障害 では男性73\%，椎骨脳底動眽循矮不全では男性60\%であ る点であった。

ましめ

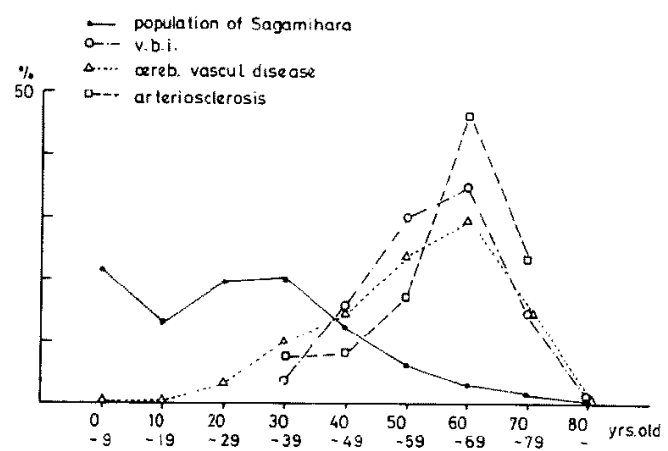

図 $\quad 2$

北里大学病院, めまい外来ならびK平衡機能検査室を

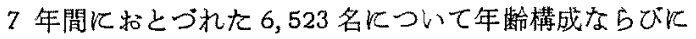
疾患列分類の調查をして次の結論至得た。

1. 60藏以上の高龄者の上率各高い，(16.8\%)

2.60歳以上のむのでは末梢前庭性障害より中枢障害の 屯の加多い.

3. 中枢障害で活60歳以上の屯のの比率が多い.

4. 中枢障害加60藏以上に多い原因は脳血管障害の增加 による。

文献

1. 水越鉄理・他，厚生者特定疾患メ二エール病調查研 究班によるメ二エール病疫学調查と症状調查, 耳鼻臨 床 70: 增 5，1669-1686，1977.

2. 重山正邦: 脳血管障害の疫学, 神経学 (沖中重雄監 㣠）南江堂，東京 1976,pp.84-89.

質問 并元俊夫（大阪市大）当科では高柃者程, 眼 层系の異常よりむしろ，体平衡の異常が渚明であること が多いが貴院に和いてはどうか。応答 德增厚二今 回は検查所見については触れなか⿰力た。 ETT, OKP の

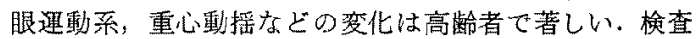
により違いがあるが，年龄変化か，疾患化上るかの鑑別

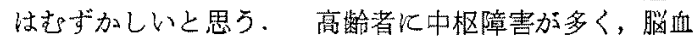
管障害が增加がその原因として重要である。これらは出 血, 硬塞 (血栓, 栓塞) TIA衣どを合もものでその集計 を示した、動摇病について主訴とする比率が発表の結果 になった.

(B 82-1121-25582)

\section{8. 外傷性 MLF症候について}

\section{野末道彦・星野和之・矢野 純・市村恵一（浜松医大）}

はじめに

MLF 症候と呼ばれる症状を要粷すると次のごとくな る、寸度わる 1。障害側の眼の内耺の障管, 2. 健側を 注視させた時，外転眼に単眼性の眼振がタられること， 3. 輻轑の垶害は認められないことである。
このような MLF 症侯を起こす病长として血管陪害，

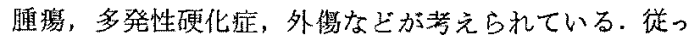
てその病柴の範国により, MLF 症候も一側性のものと 両側性のものとがある。血管障害では一般に一側性のも

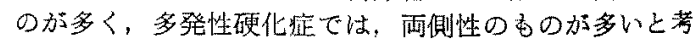

